\title{
Redesign of Library Spaces: A Collaborative Project with Engineering Stu- dents
}

\section{Aleshia Huber, Binghamton University}

Aleshia Huber is the Engineering Librarian at Binghamton University. She has a B.S. in Chemistry and an M.S. in Library and Information Science, both from the University of Illinois Urbana-Champaign. Her interests include information literacy instruction and usability studies.

\section{Jill Dixon, Binghamton University}

Associate Librarian Jill Dixon serves as the Director of Public Services at Binghamton University Libraries. She oversees the development and implementation of innovative services and programs for Reader Services, Research and Instructional Services and three branch libraries. Her interest include library management, space design, information literacy and public services. She formerly served as the Engineering Librarian at Binghamton.

\section{Ms. Sandy Card, Binghamton University}

Sandy Card is an Associate Librarian at the Binghamton University Libraries where she is currently the Director of Technical Services. Her interests include information organization and retrieval and the effective use of library management systems to provide easy and accurate discovery. 


\title{
Redesign of Library Spaces: A Collaborative Project with Engineering Students
}

\begin{abstract}
This paper describes Binghamton University Libraries' (Libraries) relationship with an industrial engineering senior design course by serving as a client in two different capstone projects. The Librarians involved were the Director of Public Services, the Director of Technical Services, and the Engineering Librarian. Each project involved a group of engineering students who were tasked with redesigning a library space to meet the needs of its users, one a public service space and the other a technical services space. The two groups of students used their engineering skills to evaluate the current space and study its users to then craft and model a redesign. Additionally, they had the opportunity to receive assistance concerning each project from a professional project design engineer employed by the university. The students attended weekly meetings with the Librarians and staff involved to update and receive feedback on their progress. The Libraries were able to provide the students with valuable experience in what it is like to work as a professional engineer in the field and helped them to understand the high level of communication necessary to do so. The students learned how a library functions and the necessity of understanding the organization's operations in order to be able to fulfill the client's needs. By serving as a client, Librarians involved in the process learned first-hand how to support engineering education and information needs. The Librarians were involved with the student's workflow and understood when and why information was needed. The projects concluded with well thought out and extensive proposals for the redesign which have the potential to be a basis for future renovations.
\end{abstract}

\section{Background}

In spring 2015, Librarians at Binghamton University sought new opportunities to collaborate with teaching faculty and students. A variety of ideas were discussed, including creating a forcredit internship program for Binghamton University students from various academic disciplines 
to work on library projects. One of the potential projects identified was redesigning various library spaces - both public and staff areas.

When investigating possible campus internship programs for these projects, the Director of Public Services and Director of Technical Services were invited to present two space renovation projects to Industrial and Systems Engineering (ISE) students enrolled in their senior capstone design project. The presentation included a tour of the main library (Bartle Library). The ISE students were given an assignment to identify design problems that would require their engineering expertise. The presentation and the student assignment sparked the idea for the Libraries to serve as a client for 2015-16 ISE senior design capstone projects which are teambased and held over two semesters.

Based on the Accreditation Board for Engineering and Technology (ABET) accreditation criteria $^{1}$, the ISE senior design capstone project goals are for students to apply their "knowledge and techniques acquired in the program to the solution of a real-world problem." ${ }^{2}$ The Libraries would serve the role of a "real-world" client with actual design projects. In addition, the ISE program educational objectives include "an ability to communicate effectively." 3 The project provided valuable experience for the students to develop their communications and interpersonal skills from the perspective of serving a client's need.

For the Libraries, the senior design projects fulfilled two objectives. Librarians were fully imbedded in an actual engineering course in a non-traditional manner - as a client. This provided insight into engineering curriculum and student information needs. The projects also provided a comprehensive design review of two library spaces, including proposals for possible extensive renovation, from an engineering perspective.

\section{Literature Review}

Senior design capstone projects are common within engineering education as a tool to synthesize what students have learned throughout their undergraduate program ${ }^{4}$ and to gain additional valuable "soft skills" 5,6 such as teamwork and communication skills, and to model the engineer- 
client relationships that will be needed in their professional careers. According to Goldberg ${ }^{7}$, senior capstone projects are "the most important courses our engineering students will take in their undergraduate programs. They provide students with an opportunity to apply what they have learned in previous years and develop their communication (written, oral, and graphical), interpersonal (teamwork, conflict management, and negotiation), project management, and design skills."

Librarians typically are involved with engineering curriculum and capstone projects from the perspective of information literacy and research skills. Examples of engineering faculty and librarian collaborations include developing conceptual models of information literacy and engineering design ${ }^{8}$; creating design course or project research literature blogs 9,10 , and implementing information literacy badging programs ${ }^{11}$. Serving as a senior design capstone project client is a novel library-engineering program collaboration.

\section{Public Space Project}

In this project, the six ISE engineering students were tasked with redesigning two public space areas, the Information Commons and the East Reading Room. The Information Commons in particular is the most heavily used space within Bartle Library, offering 217 computer stations, seven printing stations, and five scanners. In addition, there are study areas, a group study room, an adaptive technology room, the reference book collection, the Research Help Desk, and the IT Help Desk. The East Reading Room is currently a space for quiet study with individual study carrels and lounge furniture.

The Director of Public Services and the Engineering Librarian met with the engineering student team on a weekly basis to provide feedback, answer questions, and introduce the students to other staff who needed to be consulted. In the first meeting, the team was tasked to determine how the space was being used, how to use the space effectively, and whether or not it currently met the needs of the patrons. With this, the students set the goals of their project to increase the utilization of the space and improve users' performance and satisfaction with the space. 
Throughout the weekly meetings, the engineering student team consulted with us to share what they were currently working on and to determine the best course of action. The first semester consisted of data gathering through a web survey distributed to all students, interviews of current users, and gate count and headcount data. The second semester focused on the analysis of the data and creation of the redesign. Many of the students' information needs were satisfied by connecting and introducing the students to other library and campus staff involved. For example, when the students were concerned about finding out how many students were in the library at one time, the students worked with Reader Services staff members who oversaw the gate count and headcount collection. They shared with the students what data was available and how it was collected, and were willing to provide the students with that data. They also shared with the students the Google form used to collect headcount data so they could perform headcounts at times of their own choosing more easily. Other library staff consulted included the Research and Instructional Services Team, the Information Commons Coordinator, and Library Technology. University staff outside of the Libraries consulted were Information Technology Services and the University engineer. Each were experts in their respective areas and provided students information and advice on the printers, computers, services, and the library building. Other information required by the students was obtained from library furniture suppliers and book shelving suppliers. The students were also given information resources specific about the Libraries and library space in general, including book chapters, articles, and reports.

The engineering student team used a variety of skills learned throughout their engineering courses to collect and analyze data and optimize the space design. Initial data gathering was by means of an internet survey and random interviews of students who currently used the space to determine their needs and current usage of the space. Some printing data was collected through the students' observations. They then incorporated that data, along with the printing and headcount data provided, into an Arena Simulation, a discrete event simulation software. This simulation was used to determine the most optimal printing model. The simulation was run with the current design and two suggested redesigns. The students also used AutoCAD to create visuals on the final redesign. Human factors and ergonomics were considered throughout the project with a particular area of focus on the furniture choices and layout. 
The final redesign (see Appendix A) was presented to the entire library staff, including the Dean and library faculty. The redesign of the East Reading Room was a dramatic change; it converted the individualized study area into 23 group study rooms. Twenty-one of these rooms held up to four students, and the other two were larger and held up to 10. Each group study room had an iPad located outside the door so patrons could reserve the room as they entered. There was a general iPad located just outside the East Reading Room so patrons could reserve rooms in advance. The reservation system on the iPad used the Libraries' current room reservation system, and was accessible through the web for personal device use as well. With the East Reading room converted to group study, the students' design removed the group study room and practice presentation room from the Information Commons. The Information Commons redesign optimized the space to include 70 additional computing stations for a total of 284 . It implemented their centralized printing hub developed from the Arena Simulations. The reference collection stacks were moved to the adjacent government documents room using high-density, compact shelving. New furniture was added to all areas. Each item of furniture was selected based on ergonomic design, flexibility, and usability. Space was further optimized to include more furniture within the Information Commons alcoves, and the design removed unused coat closets to add cafe-height seating and desks. Soundproofing was added to both rooms as the students' research showed that a more quiet study space was desirable. Carpet padding was included in the East Reading Room design, and limp mass, acoustic foam, and sound paneling for both areas.

Through this project, the Director of Public Services and the Engineering Librarian were able to serve as a client of engineering students. The students learned how important it was to meet the needs of their client, which may not always be the most optimal or best option from an engineering standpoint. For instance, the students' final design relocated the Research Help Desk to the back wall. When this was presented to the entire library staff, the students received comments that the staff preferred the desk where it was, a centralized location and just past the entrance. As a client, the Libraries' were able to have an outside source examine the space and provide insight. The Information Commons was designed as a collaborative space, but through the students' research, it was discovered that most students worked individually at the workstations. They required collaborative space because they preferred to study with friends or 
colleagues nearby. Students could then openly discuss their assignments or projects with their peers.

The students also learned a lot about the library itself. They experienced first-hand how much library staff care about its public space. They learned that designing a layout and placement of tables and chairs required a lot of research and consideration. While the students were given an open budget for the project, they came to realize that renovating a library requires a considerable investment of funds. The engineering student team met with many different people throughout the project, thus learning that libraries have many layers. The Libraries itself has numerous operational departments, and even external units, such as Information Technology Services and Physical Facilities, have some control or input over the space. The students also learned a lot more about the physical space and services offered within the library. One student in the group had not even known that the East Reading Room existed before this project.

\section{Technical Services Project}

In this case study, the Director of Technical Services had an opportunity to look at space utilization possibilities due to a proposed asbestos removal project. The target space was the Technical Services area of the Libraries which consists of the Acquisitions, Cataloging, Electronic and Continuing Resources and Book Preparation units. While the currently occupied space was useable it was not optimal for our purposes. The proposed asbestos abatement provided us with an opportunity to recreate our office space to better meet the needs of the staff within the department. The option of a complete overhaul of the space was made possible since all walls within the boundaries of the department would need to be removed as part of the abatement. While staff within the department had some ideas of what could be done with the space, the decision was made to work with ISE senior design capstone students. After meeting with the professor in the class and meeting with some of the students who were interested in doing a project, five students decided that this was a project they wanted to tackle.

At the first weekly meeting with the students, a timeline was set for what would be completed and when. It was decided that the first semester would be spent collecting information on how 
the library functions, what the Technical Services staff were responsible for, and to outline the basic needs of the area. Included in the planning was the design of a survey which would be given to all Technical Services staff. The survey included questions concerning each staff members' current working conditions and questions concerning their ideal working conditions. During the second semester, the team would analyze the collected survey data and create several layout designs, including options for furniture, floor, and window options as well as the creation of a budget. They decided that they would work with AutoCad and a three dimensional (3D) design creator, Sketchup, to create several possible layouts for the reconfigured space. After a discussion of the problems, a walk-through of the area and brief introductions to the staff, it was decided that our weekly meetings were best spent by providing a forum for feedback based on the team's progress reports. It would also be an opportunity for the team to ask questions about the functions of the area and to discuss issues or problems they had run into.

At the first meeting, it was also decided that the role of the Director of Technical Services was to provide guidance and answer questions and allow the engineering team to create and carry out the project on their own. Their professor filled the role of teacher, the Director of Technical Services needed to stay the "client" in order to make the project as real as possible. The Technical Services staff (26 total members with eight clerical, 13 paraprofessional, and five library faculty) were fully informed of the project and knew that they would be asked to participate in an interview and survey by the engineering students. Since this was a real project rather than a made up one, it was important to create an atmosphere where the student team was truly in-charge and one where the Technical Services staff could openly and honestly make comments to the team. The one place the Director of Technical Services became more of a teacher was in introducing the student team to people who could help with their project. Examples of this were a university engineer and the Head of Technical Services at a similarsized university where the engineering team was planning to set up a site visit. The site visit was designed to compare the workflows of the two Technical Services areas as well as to examine their physical layouts and to speak to that staff for their impressions and comments about their workspace. The students went on the site visit and to the meetings with the university engineer on their own since neither of those activities would normally include the client. 
Once the parameters of the project were established, the engineering team started to compile information. This ranged from measuring each of the rooms, hallways, and spaces within the department to looking at the current physical makeup of the area. The team identified areas that could not be moved/changed, including the elevators and staircases, the loading dock, mechanical rooms, major hallways, and, without great expense, the restrooms. They discussed the need for staff swing space while asbestos abatement and office rebuilding took place. Some small but significant changes were quickly noted. One example of this was the door thresholds which were present in the current configuration. It took a very short time for the team to realize that pushing full book trucks over a threshold is a difficult and possibly dangerous operation and that they needed to be removed during any remodeling. Additionally, during the first semester the engineering student team interviewed and surveyed the Technical Services staff to get an understanding of workflows and best practices and listened to comments from the staff about those processes. The staff was assured that comments from both the interviews and the survey would be confidential with the aim of receiving very honest comments from the staff.

During the second semester, the engineering team used the information collected from the interviews and survey as well as their own observations to begin to draw workflow diagrams to create visual representations based on all the data. After meeting with the Dean of Libraries and visiting the similar-sized Technical Services area in another university to gain even more insight into possible problems and solutions, the team members generated a Systematic Layout Planning (SLP) chart to start the process of creating detailed design options for the area. Architectural drawings were rendered using AutoCAD though the library also asked the engineering team to create 3D illustrations which were created in Sketchup. These illustrations were later automated to show how the workflows would move through the new physical areas. During the weekly meetings with the Director of Technical Services the designs were examined and consolidated until there were four unique designs. Following more discussions, the designs were winnowed to two final designs. A last request for the engineering student team was for the creation of three budgets for the project - a bare bones, a medium, and a high-end budget so options would be available depending on the final amount of funding. 
How did this capstone project help the Technical Services and the Libraries? While the library supervisors could have suggested "renovations" after asbestos removal and probably improved the area based on their knowledge of the needs of the staff, the engineering student team brought a vision based on the staff needs that was a synergy of staff perceptions and input and the fresh view of the outside engineering team. Part of the team's planning had included an anonymous user satisfaction survey which included 25 questions ranging from those dealing with personal equipment (Which style of desk would you prefer?) to questions regarding the environment (Do you have enough lighting? and Do you need group work space?) and ended with a general call for additional comments. Sixteen out of twenty-six staff members responded to the survey allowing the team to get a focused representation of their needs and concerns. Because the engineering team included the Technical Services staff in the gathering of information, the staff recognized that they were partners in the process. It was also important that the engineering team took this information seriously and used it to formulate the final results.

At the conclusion of the semester, the engineering student team gave a presentation for any interested staff in the library. The PowerPoint they used included drawings of the current configuration of Technical Services as well as two potential new layouts (see Appendix B). It also included pictures of new desk and chair options as well as suggestions as to how the furniture could be configured. The presentation was well-attended and well-received. It gave the staff an additional opportunity to ask questions and make comments. Following the presentation, the engineering student team sent out a short feedback survey asking for the staff's preferences in layout and furniture. Most of these questions were open-ended, allowing staff to make whatever comments they felt appropriate. In the end, the primary positive outcome of the capstone project for the Libraries was generating a sense among the staff of inclusiveness for what could be a stressful change for some. It was rewarding to see this very bright team of senior engineering students tackle this real life challenge with enthusiasm and with great professionalism.

\section{Conclusion}

How did these ISE senior design capstone projects help the students? The overarching positive outcome was that it allowed each of them to pull together the classes they had taken over the past 
three years to utilize the knowledge and skills they had learned into a coalescing project. The projects were designed to meet the ABET criteria and that criteria was used to evaluate the overall projects. At the end of the assignment, the engineering students had gained knowledge of the give and take between the engineer and the client, including incorporating ideas from a very diverse group of staff stakeholders. Rather than just having to impress a professor who knew more than they did about engineering, the students learned to successfully communicate and deal with a client who knew significantly less about engineering, a more common situation in real life. In any project an engineer handles during their career, they will learn more about the type of business and/or environment they are working with. However, since in this case the project happened to be in a library, they had an opportunity to learn how a library really worked and, with that knowledge, gained research skills to be used not only as they finished their undergraduate careers but which will be important in their graduate or future work careers.

How did the projects help the Libraries? It was incredibly valuable to have an outside set of eyes examine how the space is used and how a library operates. Each group of students brought a fresh perspective to the space and through that incorporated innovation in their new designs that was not considered previously by the Libraries. Library staff are so used to their work place that it is hard to see and develop a completely new design.

The librarians gained valuable insight into the engineering curriculum and the type of information needed for their course work. Not only did the students rely on engineering-specific research and information learned through their classes (provided by the Libraries) but also needed to consult materials outside of a library's traditional engineering collection to learn about their client's industry or organization, in this case a library, to design effective spaces. The librarian assisted the students with their information gathering by introducing them to other library and campus staff who held the data that was specific to Binghamton University Libraries and were able to fully answer the students' questions. The librarian also provided books and articles from library literature so the students could research how other libraries design space. In addition, the Libraries received high-quality design proposals for renovation of two different and vital areas within the library. Other libraries can benefit from doing similar senior capstone design projects as long as viable project ideas are presented due to the significant time 
commitment. This further helps develop students' skills in real-life situations and answer their questions.

\section{Acknowledgements}

The authors wish to thank the students of the ISE senior design project groups for all of their work: Michael Bush, Franciele Ferrarezzo, Sara Kohtz, Katherine Leenig, Kyle Streb, Colleen Turner, Maggie DeMarco, Lauren Famighette, Jamie Jarett, Amanda Lemieux, and Allie Molinelli. The authors would also like to thank Bill Palmer for editing this paper.

\section{Bibliography}

1. Accreditation Board for Engineering and Technology. (2017). Criteria for Accrediting Engineering Programs, 2017-2018. Retrieved from http://www.abet.org/accreditation/accreditation-criteria/criteria-for-accreditingengineering-programs-2017-2018/.

2. Binghamton University Systems Science and Industrial Engineering Department. (2017). Undergraduate Program Curriculum. Retrieved from http://www.binghamton.edu/ssie/under-grad/undergraduate-curriculum.html.

3. Binghamton University Systems Science and Industrial Engineering Department. (2017). Objectives/Outcomes/Data. Retrieved from http://www.binghamton.edu/ssie/undergrad/objectives-outcomes.html.

4. Large, J. (2006). Communication is engineering: Responding to needs of industry in a capstone course. 2006 Annual Conference \& Exposition, Chicago, Illinois, 1-10. Retrieved from https://peer.asee.org/838.

5. Retherford, J. Q., \& Ellenburg, K. S. (2016). Impacts of a university-wide service learning program on a senior undergraduate capstone course. 2016 ASEE Annual Conference \& Exposition, New Orleans, Louisiana, 1-10. doi:10.18260/p.25548

6. Wilk, R. D. \& Anderson, A. M. (2002), Development of communication skills across the engineering curriculum. 2002 ASEE Annual Conference \& Exposition, Montreal, Canada, 1-14. Retrieved from https://peer.asee.org/10826.

7. Goldberg, J.R. (2007). Capstone design courses: Producing industry-ready biomedical engineers. doi:10.2200/S00097ED1V01Y200709BME015 
8. Fosmire, M. (2012). Information literacy and engineering design: Developing an integrated conceptual model. International Federation of Library Association and Institutions, 38(1), 47-52. doi: 10.1177/0340035211435071

9. Tourino, G., \& King, M. W. (2013). Engineering librarians as partners of faculty in teaching scholarly inquiry to undergraduate students through curriculum integration: The biotextiles product development course blog. 2013 ASEE Annual Conference \& Exposition, Atlanta, Georgia, 1-9. Retrieved from https://peer.asee.org/19529.

10. Denick, D., \& Detweiler, J., \& Ray, C., \& Cebulski, A., \& Bhatt, J. (2009). Library smart house collaboration for information literacy development. 2009 Annual Conference \& Exposition, Austin, Texas, 1-12. Retrieved from https://peer.asee.org/5533.

11. Fosmire, M., \& Van Epps, A. S., \& Johnson, N. E. (2015). Badging your way to information literacy. 2015 ASEE Annual Conference \& Exposition, Seattle, Washington, 1-11. doi: 10.18260/p.23614 


\section{Appendix A: Public Service Current Design and Proposed Redesign}

Current Space Layout - Information Commons (two floors) and East Reading Room
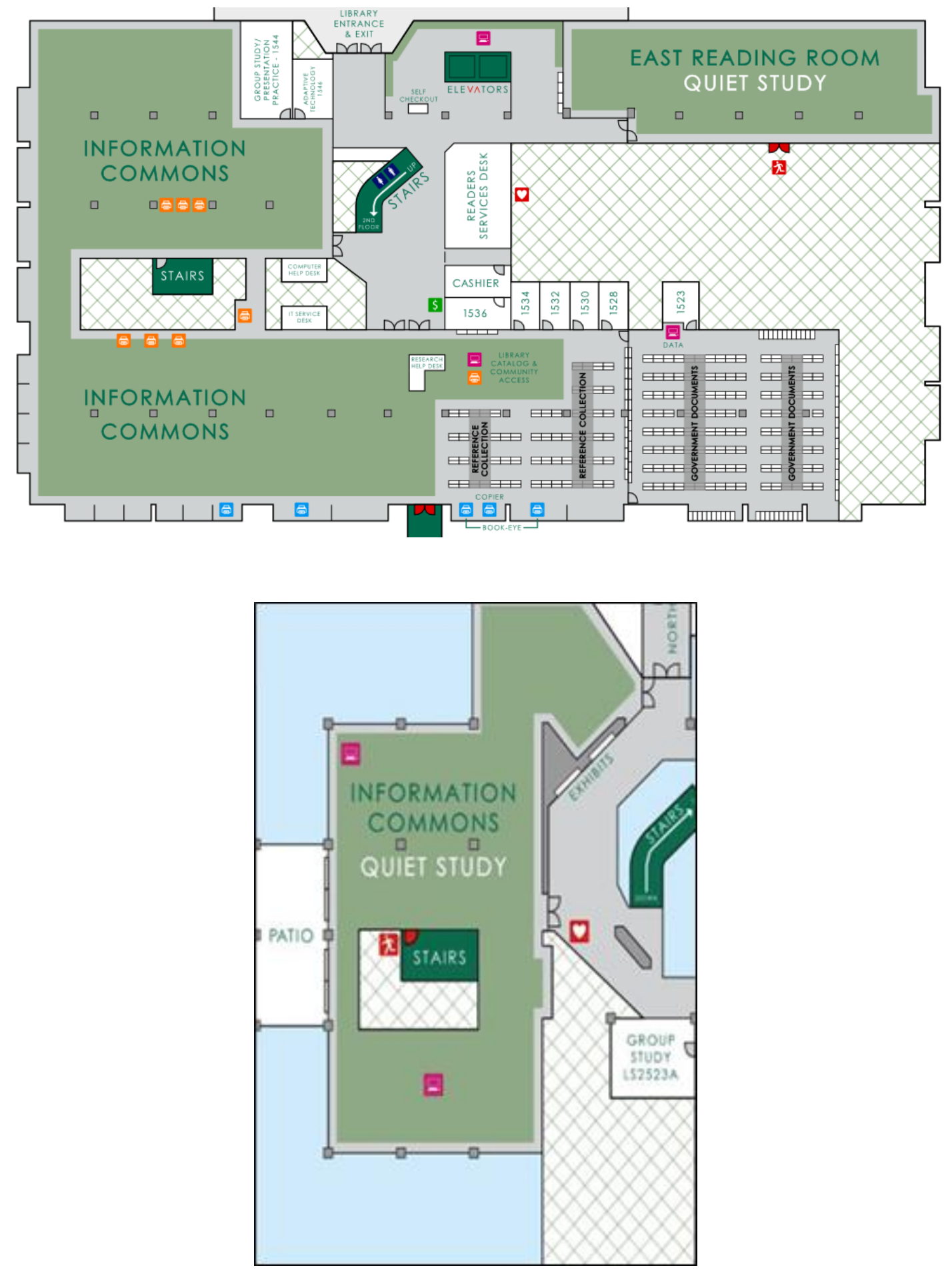
Proposed Redesign - Information Commons (Two floors)
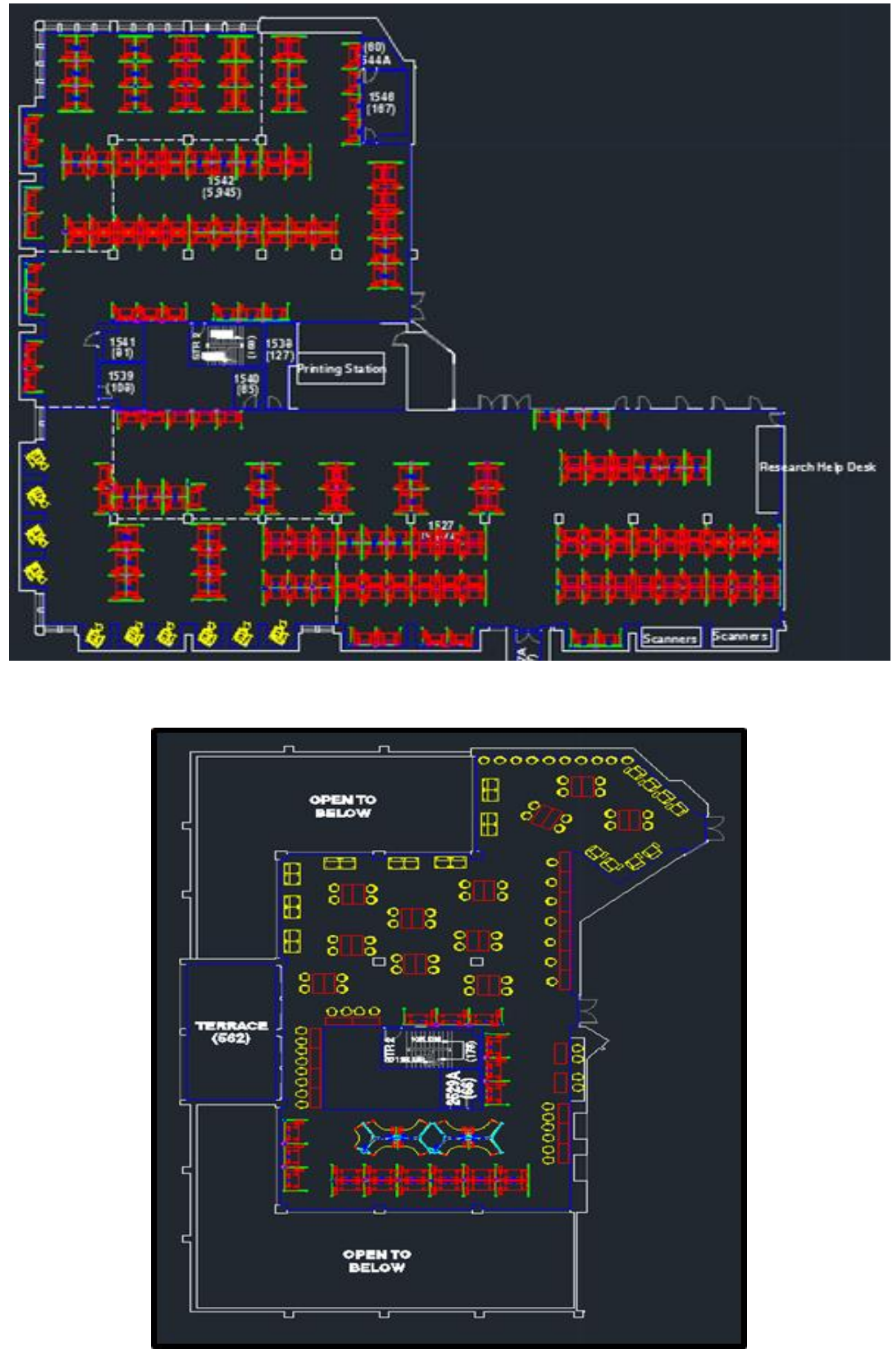
Proposed Redesign - East Reading Room

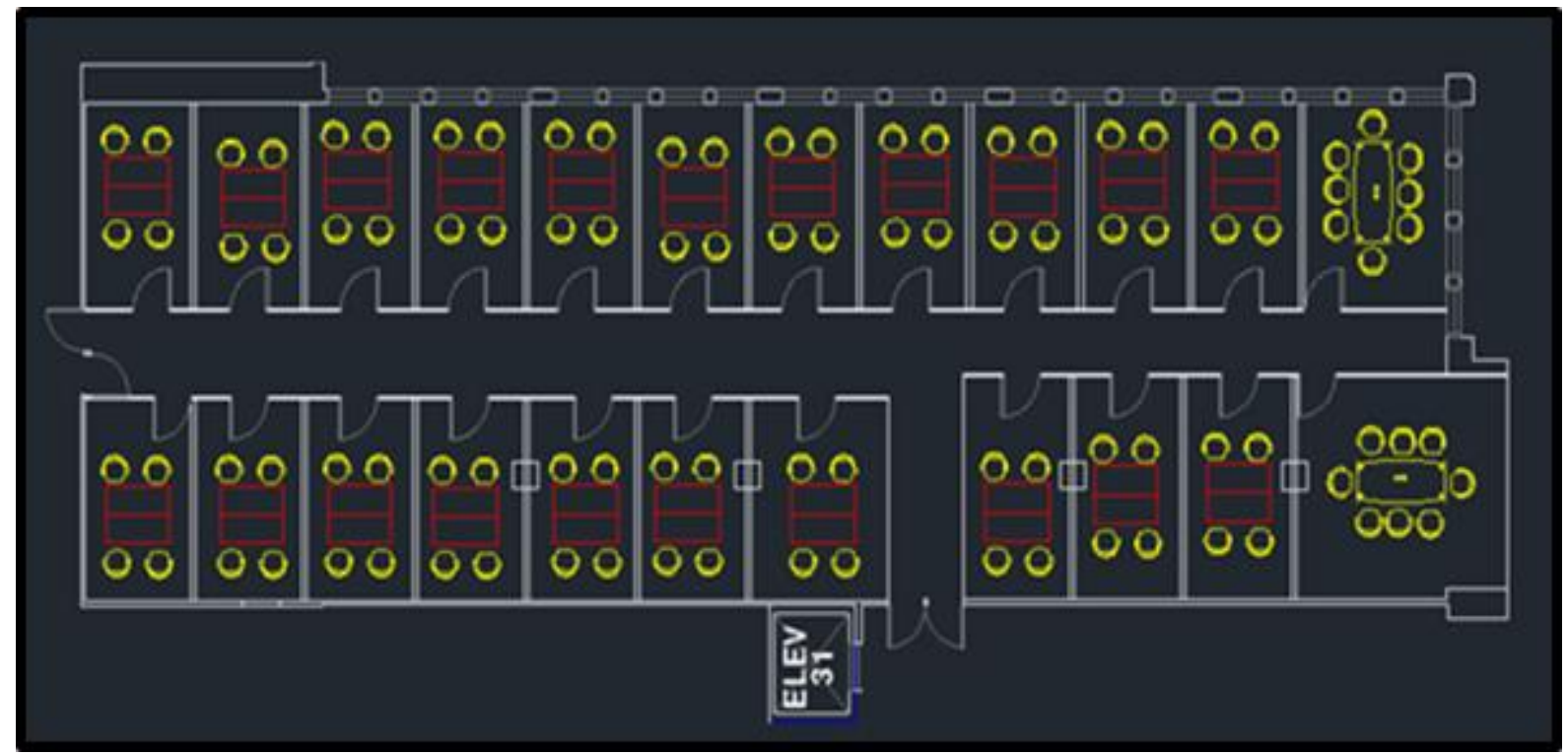

Appendix B: Technical Services Current Design and Proposed Redesign

Current Space Layout

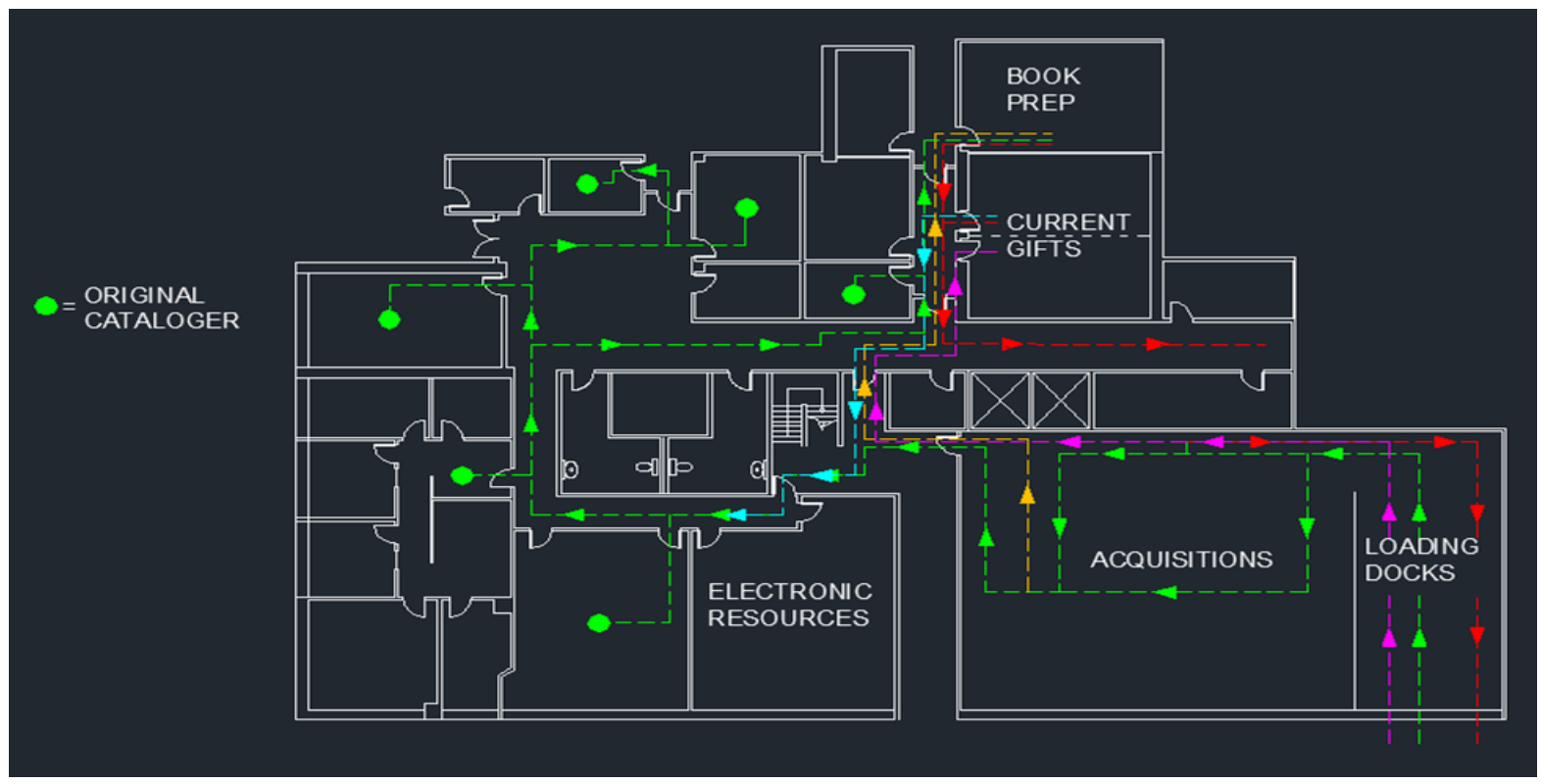




\section{Proposed Redesign 1}

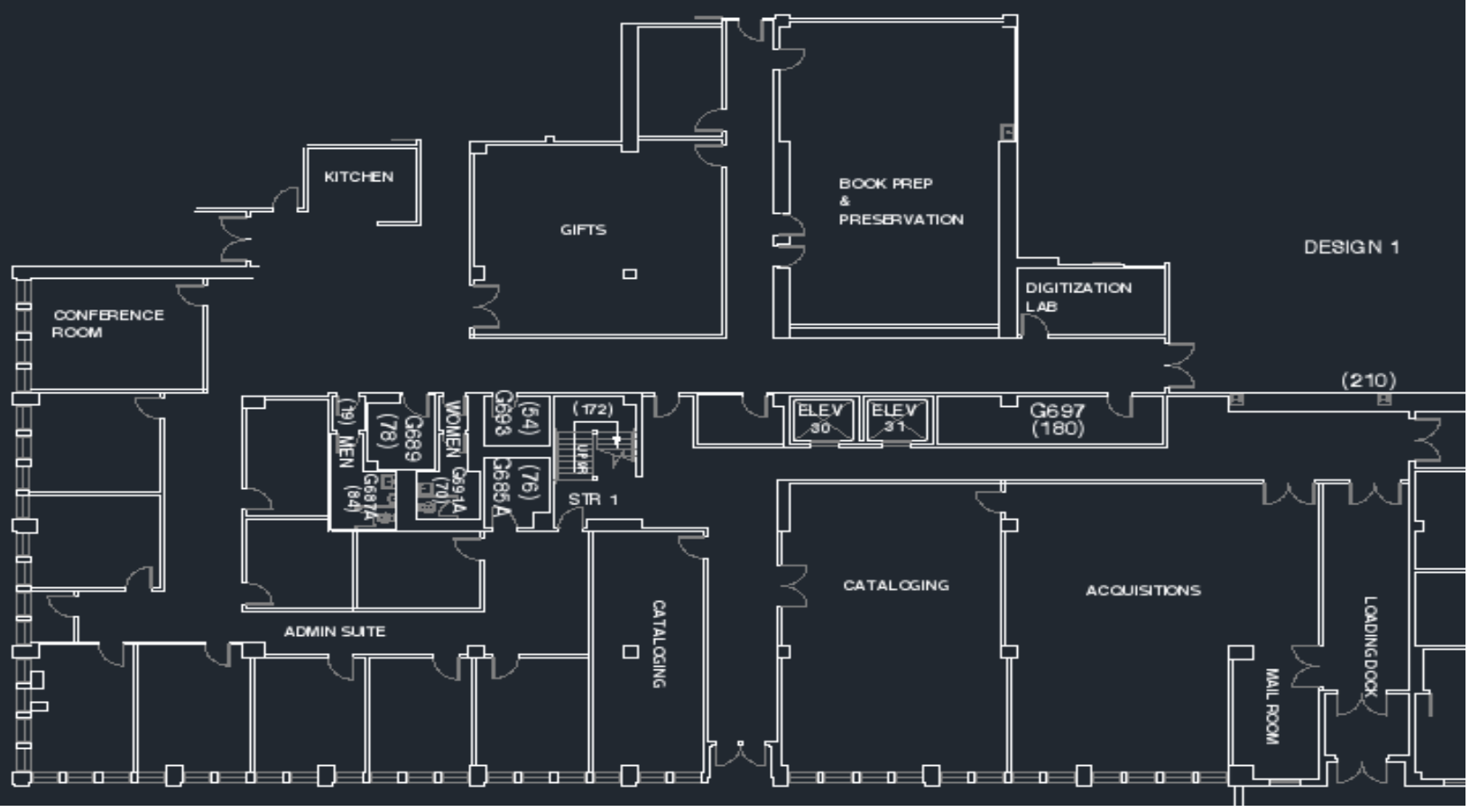

Proposed Redesign 2

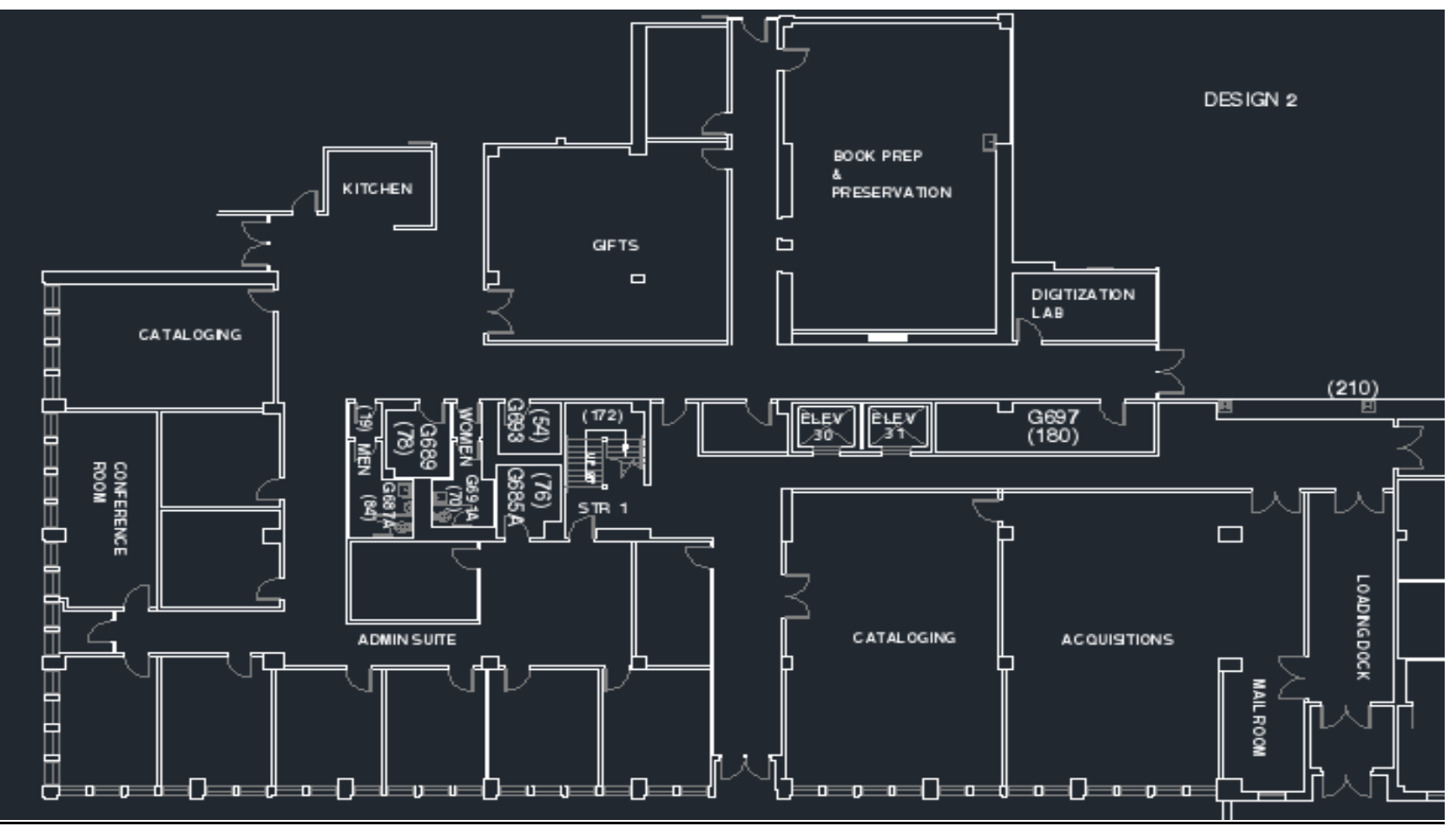

